\title{
人工受粉の時期と回数がヤマブドウの結実と果実品質に及ぼす影響
}

\author{
本間英治 ${ }^{1 *}$ ・宍戸麻依子 ${ }^{2} \cdot$ 平＼cjkstart智 2 \\ ${ }^{1}$ 山形大学農学部附属やまがたフィールド科学センター 997-0369 鶴岡市高坂 5-3 \\ 2 山形大学農学部 997-8555 鶴岡市若葉町 1-23
}

\section{Effects of Timing and Frequency of Artificial Pollination on Fruit Set and Berry Quality in Japanese Wild Grape Vitis coignetiae Pulliat}

\author{
Hideharu Honma $^{1 *}$, Maiko Shishido ${ }^{2}$ and Satoshi Taira ${ }^{2}$ \\ ${ }^{\prime}$ Yamagata Field Science Center, Faculty of Agriculture, Yamagata University, Takasaka, Tsuruoka, Yamagata $997-0369$ \\ ${ }^{2}$ Faculty of Agriculture, Yamagata University, Tsuruoka, Yamagata 997-8555
}

\begin{abstract}
To stabilize the berry production in a dioecious Japanese wild grape, Vitis coignetiae Pulliat, we studied the flowering patterns in female and male plants and the effects of timing and frequency of artificial pollination on fruit set and berry quality. The flowering periods of female and male plants were ten and nine days, respectively. The highest fruit set in the fruit cluster (54.6\%) after performing artificial pollination twice was obtained using the pollen of male plants on the second and fifth days of the flowering period. With a single artificial pollination, we obtained higher fruit set with pollination on the fifth day $(46.2 \%)$ than with pollination on the second day $(24.0 \%)$. The soluble solid concentration in berry juice was higher in fruit with pollination on the fifth day. We also found it useful to use pollen from Vitis cultivars with artificial pollination to obtain a high percentage of fruit set in Vitis coignetiae Pulliat.
\end{abstract}

Key Words : flowering pattern, pollen, shoot growth, stable fruit production キーワード : 安定果実生産, 花粉, 開花パターン, 新梢成長

\section{緒言}

ヤマブドウ（Vitis coignetiae Pulliat）は日本国内に広く分 布する野生ブドウの一種である。一般のブドウとは異なり 雌雄異株であるため，その年の受精の良否が結実量に大き く影響する (望岡, 1999)。 そのため, 雌株と雄株を混植し たり，雌花に雄花の花粉を人工受粉して安定生産を図って いるが，気象条件などによっては，雌株と雄株の開花時期 が一致しない年もあり問題になっている（田代，1997）.

筆者らは, ヤマブドゥの人工受粉に使用する花粉を十分 量確保するために, ヤマブドウ花粉の長期貯蔵方法を検討 した。 その結果，前年に採取した花粉をジェチルエーテル 中に入れて低温 $\left(8^{\circ} \mathrm{C}\right)$ で貯蔵すれば，翌年の人工受粉に 利用できることを明らかにした（本間ら，2003）。

しかし，人工受粉の時期や回数がヤマブドウの結実率や 収量ならびに果実品質に及ぼす影響については，未解明な

2006 年 5 月 31 日 受付. 2006 年 10 月 12 日 受理. 本報告の概要は園芸学会平成 18 年度春季大会 (千葉) で発表し た。また，本研究の実施には，日本学術振興会からの科学研究 費補助金（奨励研究，課題番号：17922020）の交付を受けた.

* Corresponding author. E-mail: hdhhonma@jm.kj.yamagata-u.ac.jp
点が多い（難波，1995; 清野，未発表）。

そこで，本報告ではヤマブドウの雌株抒よび雄株のそれ ぞれの開花パターンを明らかにするとともに，人工受粉の 時期と回数が結実率と収穫時の果実品質に及ぼす影響につ いて調査した。なお，ヤマブドウの花粉の代わりにより入 手の容易なブドウ栽培品種の花粉を人工受粉に用いること も考えられる，そこで，ブドウ栽培品種の花粉をヤマブド ウの人工受粉に用いたときの結実率と果実品質に及ぼす影 響についても検討を加えた。

\section{材料および方法}

山形大学農学部附属農場（鶴岡市）で栽培している 30 年 生のヤマブドゥ（自根）の雌雄各 1 樹（株）を供試した. 供試樹は，原則として 1 新梢当たり 2 果房を着生させるよ らに調整した。

\section{試験 1. 新梢伸長と開花パターンの調査}

雌株と雄株から無作為にそれぞれ 10 芽を選び，萌芽期， 展葉期，開花始期，満開期，開花終期および落葉期を記録 するとともに，新梢の伸長量と展葉数を萌芽期から落葉期 まで 1 週間間隔で調査した．萌芽期は芽を覆っている鱗片 がはがれて綿毛が完全に露出した時期，展葉期は第 1 葉が 
完全に展開した時期，開花始期は花穂の小花が開花を始め た時期，満開期は花穂の小花がすべて開花した時期，開花 終期は花穂のすべての小花の柱頭もしくは雄ずいが褐色に なった時期とした。 また，これとは別に，雌株と雄株の両 方に沶いて同一日に開花し始めた花穂に目印を付けてお き，満開期に至るまでそれらの中から毎日 5 花穂ずつを無 作為に採取して花穂内の小花の開花率を調査するととも に, 累積開花率を求めた。

\section{試験 2. 人工受粉の時期と回数の影響}

雌株の開花開始 2 日後に 1 回受粉する区（以下, 前期受 粉と呼ぶ), 開花開始 5 日後に 1 回受粉する区 (以下, 後期 受粉と呼ぶ), 前期受粉と後期受粉の 2 回受粉する区 (以下, 前期 + 後期受粉と呼ぶ）, 自然受粉区（以下，放任受粉と 呼ぶ）および花粉遮断区（以下, 無受粉と呼ぶ）を設けた。 花粉は, 4 月 21 日から雄株の新梢にポリエチレン袋をかけ て開花を促進させた花穂から，前報（本間ら，2003）と同様 の方法で採取した. 花粉発芽率も前報と同様の条件で花粉 を培地に置床後, 6 時間培養した後に求めた.

受粉は上記の方法で得た花粉（発芽率 16\%）を石松子で 約 2 倍に希釈したものを用いて行った. 寸なわち, 各処理 区当たり供試樹（雌株）から無作為に選んだ 10 花穂中の開 花しているすべての小花に, 人工受粉用のぼん天を用いて 受粉した.なお，放任受粉以外の処理区の花穂には，開花 の直前から紙袋（リンゴ用果実袋）をかけ，人工受粉を行 なら処理区においては，受粉を行なら時だけはずして，受 粉後ただちに再び被袋した. 除袋はすべての落花が終了し, 結実の有無が確認された時点で行った.

各処理区の果房が注棌収穫熟度に達した時点(10月2日) で果房を一斉に採取し, 各処理区ごとに, 果房当たりの果 粒数, 果粒重, 果粒当たりの種子数抢よび種子重, 果皮中 のアントシアニン含量, 果汁の屈折計示度拈よび滴定酸含 量を調査した。結実率は, 開花期にすべての供試花穂の小 花数を樹上でカウントし，それらに対する收穫時の着果数 の割合として果房ごとに算出しょうとしたが，各処理区の 果房ごとに付けた番号札の一部が収穫前の暴風雨によって 喪失してしまったため，果房ごとの結実率を算出すること ができなくなった，そのため，結実率は各処理区全体の小 花数に対する着果数の割合として算出した.

\section{試験 3. 栽培品種の花粉の影響}

‘マスカット・オブ・アレキサンドリア’（以下，マスカッ トと略す）と ‘グローコールマン’ の花粉を用いた. これ らの花粉は, 開花時期が山形県よりも早い岡山県で栽培さ れている成木から採取し, サンプル瓶中に紙で包んだシリ カゲルとともに封入し， $5{ }^{\circ} \mathrm{C} て ゙$ 輸送したものを用いた．試 験 1 と同様の方法で求めた花粉の発芽率はマスカットでは $18.4 \%$ 'グローコールマン’ では $6.1 \%$ であったため, 人工 受粉にはマスカット花粉は石松子で 3 倍に希釈したものを 用い, ‘グローコールマン' は希釈しない純花粉を使用し た. 受粉は試験 2 の前期 + 後期受粉と同様の方法で行い,
供試樹から無作為に選んだ各 10 花穂に受粉した. 結実率と 收穫時の果実品質の調査は試験 2 と同様に行った.

\section{結果および考察}

\section{試験 1. 新梢伸長と開花パターンの調査}

調査した雌雄各 10 新梢の萌芽は, 雌株は 4 月 13 日〜 14 日, 雄株は 4 月 13 日〜 15 日. 展葉は, 雌株は 4 月 27 日〜 28 日, 雄株は 4 月 27 日〜 29 日. 落葉は, 雌株は 11 月 10 日, 雄株は 11 月 17 日であり落葉期に 1 週間の差が認めら れたが, 雌株と雄株との間で大差がみられなかった。雌株 と雄株の新梢の伸長量は 6 月 16 日,葉数は 6 月 2 日までほ とんど差が認められなかったが，それ以降は雌雄の成長の 間に大きな違いが現れた (第 1 図)。この違いが出現し始め た時期は両株の開花終期とほぼ一致していることから, 雌 株では開花もしくは受精後に多くの同化養分が果粒の成長 に使用されるため, それ以降の新梢伸長が停滞したものと 推察された. 雌株と雄株それぞれ 10 新梢の開花期間は, 開 花始日は，雌株は 5 月 31 日〜 6 月 5 日，雄株は 5 月 31 日 $\sim 6$ 月 3 日. 満開期は, 雌株は 6 月 2 日〜 7 日, 雄株は 6 月 2 日〜 7 日. 開花終日は, 雌株は 6 月 6 日〜 10 日, 雄 株は 6 月 5 日〜 9 日であった. 花穂開花始日を花穂間で比

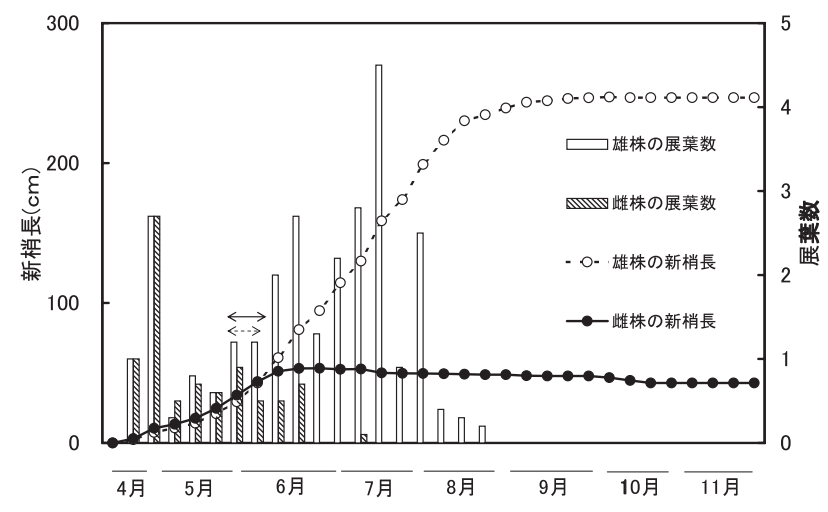

第 1 図 ヤマブドウの雄株および雌株の新梢長および展葉数 の経時的変化

$\longleftrightarrow$ は雌株の開花期間を表す（5月 31 日〜 6月 10 日） $\ll->$ は雄株の開花期間を表す（5月 31 日～6月 9 日）

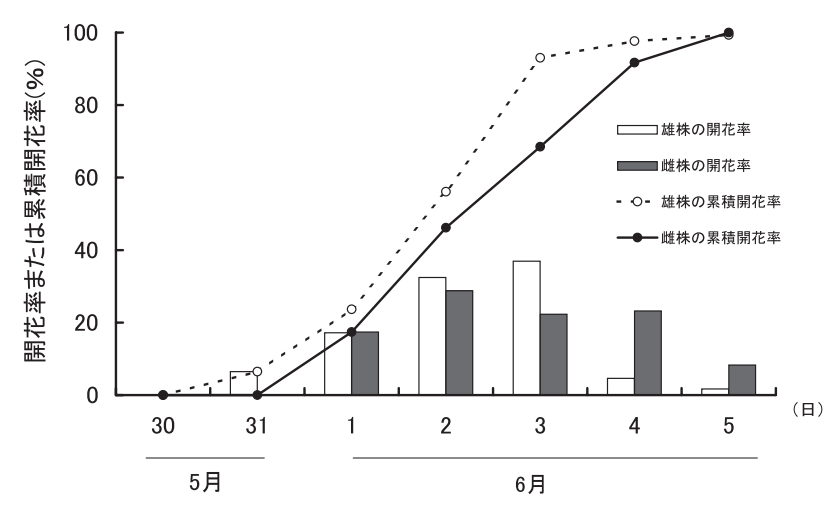

第 2 図 ヤマブドウの雄株抢よび雌株の開花率の経時的変化 
較すると，雌株で 5 日，雄株で 3 日の差が認められた。雌 株では，最も早く開花した花穂が満開を迎えた時点でも同 じ株内にはまだ開花が始まっていない花穂が混在してい た。調査対象とした花穂の中で，最も早く開花し始めた花 穂の開花始日から最も遅く開花を終えた花穂の開花終日ま での日数 (開花期間) は, 雌株で 10 日，雄株で 9 日であっ た．累積開花率は，開花始期の雌株では $17.4 \%$ ，雄株では 6.5\%であった．また，累積開花率が 90\%を超えたのは，䧳 株，雄株ともに開花始期後から 3 日であった（第 2 図）.

\section{試験 2.人工受粉の時期と回数の影響}

前期受粉日は 6 月 1 日, 後期受粉日は 6 月 4 日であった. 結実率は前期 + 後期受粉が最も高く, 以下，後期受粉，前 期受粉，放任受粉，無受粉の順に低下した（第 1 表）。前期 受粉と後期受粉および前期 + 後期受粉の結実率に差が生 じた原因として，受粉時の開花率の違いの影響が大きいも のと考兄られる。前期受粉日（6月 1 日）の累積開花率は $17.4 \%$ であった（第 2 図）が，累積開花率の調査には 6 月 1日に開花始期を迎えた花穂を用いて調査しているため, 前 期受粉の対象となった花穂の開花率としては，開花開始後 2 日（6月 2 日）の累積開花率である $46.2 \%$ より近いもの と推察される. 後期受粉日の累積開花率は, 同様の理由か らほぼ100\%であったと考兄らる。

木村ら（1996）はヤマブドウの雌花の開花後 4 日以上を 経過した雌ずいでは受粉しても花粉管が子房内に到達する ものが汇とんど認められないと報告している．本調査の後 期受粉日の花穂の中には開花後 4 日以上を経過した小花が あったと考えられることから，このことが前期 + 後期受粉 よりも後期受粉で結実率が低くなった原因の一つであると 考えられる.なお，無受粉の果粒は小さく，すべてが無種 子であるか，もしくはしいなのみを含んでいた．

収穫時の果粒重は, 前期受粉および前期 + 後期受粉で無 受粉および放任受粉より有意に大きかった（第 1 表）。ま た，果房当たりの果粒数は，前期 + 後期受粉が無受粉扣よ び前期受粉より有意に多かった. 着果量を果粒重 $\times$ 果粒数 と考劣て比較した場合, 前期 + 後期受粉が後期受粉を除い たすべての処理区より有意に高かったことから，実際の収
量も多くなると思われた．果粒当たり種子数は後期受粉が 放任受粉，前期受粉および無受粉より有意に多かった（第 2 表)。また，前期受粉の果粒重は後期受粉に近似している ものの果粒当たりの種子数は有意に少なかった．このこと は前期受粉では果粒に占める果肉の割合が多いことを示し ている。一方，果汁の屈折計示度は後期受粉が前期受粉お よび無受粉より有意に高かった。これは後期受粉では果粒 当たりの種子数が多く，果粒のシンク力が高かったことが 一因と考兄られる. 果汁の滴定酸含量は前期 + 後期受粉が 後期受粉を除くすべての処理区より有意に低かった，果粒 当たりの種子重は無受粉を除いて各処理区間に有意な差異 は認められなかった。果皮中のアントシアニン含量にはす べての処理区間で有意な差異は認められなかった(第2表).

\section{試験 3．栽培品種の花粉の影響}

果粒重はマスカット花粉受粉区が ‘グローコールマン’ 花粉受粉区よりも有意に大きく，結実率にも約 $15 \%$ の差が 生じた (第 1 表). 果実品質には両者の間に有意な差は認め られなかった (第 2 表)。本調査では，マスカットの花粉を 石松子で 3 倍に希釈し，雌花の柱頭に付着する発芽する能 力があると判断される花粉数を 'グローコールマン' とほ ぼ同等にして受粉試験を行ったにもかかわらず，果粒重と 結実率にこのような差が生じた原因としては，両品種の純 花粉の発芽率にマスカットが $18.4 \%$, ‘グローコールマン’が 6.1\%と大きな差があったためと考えられる.

Kimura ら (1998a) は，ヤマブドウの人工受粉に打いて, マスカットの純花粉（発芽率 41\%）を受粉した場合と石松 子で約 3 倍あるいは約 10 倍に希釈した花粉を受粉した場合 を比較した結果，いずれの場合にも花粉管は珠孔まで到達 していたと報告している．このことは，発芽率が $41 \%$ の花 粉を 10 倍に希釈した場合でも受精するのに十分な数の花 粉が柱頭上に付着していることを示している. これらの結 果から考觉ると，本研究で'グローコールマン’を用いた ときの結実率が低下した原因は，花粉の発芽率が低いとい らよりむしろ花粉の発芽から受精に至るまでの生理的活性 の差に基づいているものと推察される。いいかえれば，本 研究に用いたマスカットの花粉は人工培地上での発芽率が

第 1 表 人工受粉の時期と回数がヤマブドウの結実率，果粒重，果房当たり果粒数および着果量に及ぼす影響

\begin{tabular}{lcccc}
\hline \hline 処理区 & 結実率 $^{\mathrm{z}}(\%)$ & 果粒重 $(\mathrm{A})(\mathrm{g})$ & 果房当たり果粒数 $(\mathrm{B})$ 着果量 $(\mathrm{A} \times \mathrm{B})(\mathrm{g})$ \\
\hline 無受粉 & $(24.7) \mathrm{y}$ & $(0.39) \mathrm{c}$ & $(23.2) \mathrm{bc}$ & $(9.14) \mathrm{d}$ \\
放任受粉 & 23.7 & $1.13 \mathrm{~b}$ & $32.8 \mathrm{abc}$ & $37.1 \mathrm{c}$ \\
前期受粉 & 24.0 & $1.40 \mathrm{a}$ & $31.1 \mathrm{bc}$ & $43.6 \mathrm{bc}$ \\
後期受粉 & 46.2 & $1.39 \mathrm{ab}$ & $35.7 \mathrm{abc}$ & $49.5 \mathrm{abc}$ \\
前期 + 後期受粉 & 54.5 & $1.43 \mathrm{a}$ & $50.8 \mathrm{a}$ & $72.5 \mathrm{a}$ \\
\hline マスカット・オブ・アレキサンドリア & 47.9 & $1.47 \mathrm{a}$ & $47.8 \mathrm{ab}$ & $70.1 \mathrm{ab}$ \\
グローコールマンx & 33.3 & $1.12 \mathrm{~b}$ & $32.2 \mathrm{abc}$ & $36.0 \mathrm{c}$ \\
\hline
\end{tabular}

z 処理区当たりの全小花数に占める着生果粒の割合

y（）内の值は無種子ないしはしいなのみを含む果粒

$\mathrm{x}$ これらの栽培品種の花粉は岡山県から低温輸送したものを用い, 人工受粉の時期は前期 + 後期とした

同じカラム内の異なるアルファベット間には Tukey の範囲検定（5\%レベル）で有意差があることを示す 
第 2 表 人工受粉の時期と回数がヤマブドウの果粒当たり種子数および種子重と果実品質に及ぼす影響

\begin{tabular}{|c|c|c|c|c|c|}
\hline 受粉の方法 & $\begin{array}{l}\text { 果粒当り } \\
\text { 種子数 }\end{array}$ & $\begin{array}{c}\text { 果粒当たり種子重 } \\
(\mathrm{g})\end{array}$ & $\begin{array}{c}\text { 屈折計示度 } \\
\text { ( }{ }^{\circ} \text { Brix) }\end{array}$ & 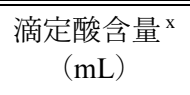 & $\begin{array}{c}\text { アントシアニン含量 } \\
\text { (O.D.) }\end{array}$ \\
\hline 無受粉 & $(1.5)^{\mathrm{z}} \mathrm{c}$ & $(0.03) \mathrm{b}$ & (11.4) cd & $(3.20) \mathrm{a}$ & $(0.36)$ a \\
\hline 放任受粉 & $1.8 \mathrm{bc}$ & $0.06 \mathrm{a}$ & $13.5 \mathrm{abc}$ & $2.48 \mathrm{bc}$ & 0.44 a \\
\hline 前期受粉 & $1.8 \mathrm{bc}$ & $0.07 \quad \mathrm{a}$ & $12.6 \mathrm{bcd}$ & $2.56 \mathrm{~b}$ & 0.46 a \\
\hline 後期受粉 & $2.6 \mathrm{a}$ & 0.09 & $15.0 \mathrm{a}$ & 2.22 & $0.40 \quad \mathrm{a}$ \\
\hline 前期 + 後期受粉 & $2.3 \mathrm{ab}$ & 0.08 & $14.8 \mathrm{ab}$ & $2.12 \mathrm{~d}$ & $0.37 \quad \mathrm{a}$ \\
\hline マスカット・オブ・アレキサンドリアw & $2.4 \mathrm{ab}$ & 0.09 & 13.1 abcd & 2.27 & $0.48 \quad \mathrm{a}$ \\
\hline グローコールマン w & $1.9 \mathrm{abc}$ & $0.07 \quad \mathrm{a}$ & 12.5 bcd & $2.17 \mathrm{~cd}$ & $0.41 \quad \mathrm{a}$ \\
\hline
\end{tabular}

z（）内の值は無種子ないしは“しいな”のみを含む果粒

$\mathrm{y}$ 直径 $9 \mathrm{~mm}$ の果皮ディスク 5 枚を $220 \mathrm{~mL}$ の $1 \% \mathrm{HCl}-\mathrm{MeOH}$ で抽出したときの $530 \mathrm{~nm}$ の吸光值

$\mathrm{x}$ 果汁 $1 \mathrm{~mL}$ を中和するのに要した $0.1 \mathrm{~N} \mathrm{NaOH}$ の量

wこれらの栽培品種の花粉は岡山県から低温輸送したものを用い，人工受粉の時期は前期 + 後期とした

同じカラム内の異なるアルファベット間には Tukey の範囲検定（5\%レベル）で有意差があることを示す

高いばかりでなく，雌しべの柱頭上でもより高い生理的活 性を有して损り，そのことが結果として高い結実率に反映 したものと思わ机る。

これらのことから，マスカット花粉を用いた場合の結実 率 (47.9\%) b, ヤマブドウ花粉の前期 + 後期処理の結実 率（54.5\%）にはやや劣るものの，ヤマブドゥ花粉の前期 受粉より高く後期受粉とほぼ同等で，果実品質も遜色がな かったことから，花粉を生理的活性が高い状態で利用でき ればブドウ栽培品種もヤマブドウ人工受粉の花粉源として 有用であると考えられた。

以上の実験結果より, 雌株花穗の開花期間の長さを考慮 すると, ヤマブドウの人工受粉では開花の前期と後期に 2 回受粉することが望ましいと考えられた。 また，やむを得 ず 1 回のみの人工受粉を実施する場合は後期受粉の方が有 効と思われた。 ただし，ヤマブドウは開花後 2 日の雌花が 最も受精能力が高いといら報告があることから（Kimura ら, 1998b), 1 回のみの人工受粉の時期を決めるに際には, 受精能力の高い状態の花が多い時期をその樹体の開花パ ターンに照らし合わせて判断する必要があるものと思われ る.さらに, 栽培品種の花粉を使用した場合でも高い結実 率が得られたことから，適切な貯蔵ができれば，ヤマブド ウの人工受粉用の花粉源として有用であると考えられた.

\section{摘 要}

ヤマブドウ果実の安定生産技術の確立に関する基礎的知 見を得るため, 雌株と雄株の開花パターンを調査するとと もに，雄株花粉を用いた人工受粉の時期と回数が結実率と 収穫時の果実品質に及ぼす影響を調査した。 また，ブドウ 栽培品種の花粉を用いた場合の人工受粉の効果をヤマブド ウ花粉と比較した.

ヤマブドウの開花期間は雌株が 10 日, 雄株が 9 日であっ た. 結実率は開花の前期（開花始期後 2 日）と後期（開花 始期後 5 日) の 2 回人工受粉した場合が最も高かった $(54.5$ \%). 1 回の夕人工受粉する場合は, 結実率は後期受粉 (46.2
\%）が前期受粉（24.0\%）よりも高かった. 収穫時の果汁 の屈折計示度は, 後期受粉が前期受粉より高い傾向が認め られた。

栽培品種の ‘マスカット・オブ・アレキサンドリア’の 花粉（発芽率 18.4\%を 3 倍希釈）と ‘グローコールマン’ の花粉（発芽率 $6.1 \%$ ) を人工受粉した場合の結実率はそれ ぞれ 47.9\%拈よび 33.3\%で大差が認められたが，生理的活 性の高い花粉を確保できればヤマブドウ人工受粉の花粉源 として利用可能であると考えられた.

謝 辞 本調査で使用したブドウ栽培品種の花粉を提供 いただいた岡山大学農学部の久保康隆博士ならびに調査に 協力いただいた山形大学農学部果樹生産学研究室の学生諸 氏に深く感謝します。

\section{引用文献}

本間英治・遠藤正昭・高橋秀典・平 智. 2003. 有機溶 媒を用いたヤマブドウ花粉の長期貯蔵に関する研究. 園学研. 2: 289-292.

Kimura, P. H., G. Okamoto and K. Hirano. 1998a. Artificial pollination in Vitis coignetiae Pulliat. Vitis 37: 83-86.

Kimura, P. H., G. Okamoto and K. Hirano. 1998b. The mode of pollination and stigma receptivity in Vitis coignetiae Pulliat. Amer. J. Enol. Vitic. 49: 1-5.

木村パウロ広・岡本五郎・平野 健・植木啓司. 1996. ヤマ ブドウ（Vitis coignetiae Pulliat）の受粉と受精について. 園学中四国支部要旨. $35: 3$.

望岡亮介. 1999. 栽培の基礎. ヤマブドウ. p. 11-12. 農業 技術体系 (果樹編). 7. 特産果樹. 農文協. 東京.

難波勉治. 1995. ヤマブドウの自然及び栽培条件下に括け る成長・開花・結実特性に関する研究. 山形大農学部 附属農場報. 6 別冊 : 45-49.

田代重哉. 1997. 山形県におけるヤマブドウ栽培. p. 1729. 難波勉治・田代重哉・藤根勝栄著. 特産くだもの. ヤマブドウ. 日本果樹種苗協会. 東京. 